\title{
The Problems of Taxpayers Compliance, Ethics, Tax Audit and Tax Penalty: Evidence from Samarinda
}

\author{
Harista Bangun $^{1}$, Yoremia Lestari Ginting ${ }^{2}$, Rusdiah Iskandar ${ }^{3}$ \\ Faculty of Economics and Business, Mulawarman University, Indonesia \\ 1 harista13emhs. feb.unmul.ac.id \\ ${ }^{2}$ yoremia.lestari.ginting@feb.unmul.ac.id \\ ${ }^{3}$ rusdiah.iskandarefeb.unmul.ac.id
}

\begin{abstract}
Tax become the largest income sector for this country. Currently, around $77 \%$ of the Indonesian State Budget is financed from tax revenues. In Samarinda, there was a decreased level of tax compliance. As for the problem with this study is to find out whether ethics, tax audits, and tax penalties partially can improve taxpayer compliance. This study tried to determine the factors that influence compliance Taxpayers Taxpayers registered individual, especially in Samarinda Tax Office. In this study, the data were collected through questionnaires to 100 respondents using a purposive sampling method to determine the response of respondents to each variable. Then analyze the data obtained in the form of quantitative analysis. Findings indicated tax audit that had an influence on Taxpayers compliance. However, ethics and tax penalties do not affect the Taxpayers compliance. This study provides important implications for policymakers in addressing taxpayer compliance.
\end{abstract}

Keywords - ethics, tax audit, tax penalties, taxpayers compliance

\section{INTRODUCTION}

Tax revenue or income become the largest sector in Indonesia. The country can use the taxes to improve infrastructure development needs, the conduct of government and public services. Tax compliance by [1] is the taxpayer has the willingness to fulfill their tax obligations in accordance with the applicable rules without the need of holding the examination, thorough investigations, warnings or threats, in the application of legal or administrative sanctions.

Ethics studies about actions or behavior of an individual, groups, or institutions, the good and the bad. Measure to judge whether or not an action is good when viewed from the intact human nature is seen on the advantages or disadvantages for others, the ability of those actions in creating the happiness of the individual in increasing faith / spiritual consciousness of a person.
We can know or ascertain the level of tax compliance, by conducting the direct examination. Tax audit can be done in the field and in the office. Field tax audit can be done at home WP, whereas direct examination held office in the Directorate General of Taxation. In taxation, if there is no breaking the rules implementing the obligations to pay taxes, it can be fined or penalized. Just as the tax audit, the tax penalty is also very influential in improving compliance to pay taxes.

Self-assessment system which is implemented by the Indonesian government, give full credence to the taxpayer (WP) to calculate, taking into account, deposit and report the entire tax obligations [2]. In other words, taxpayers themselves determine the amount of taxes owed.

TABLE I

LEVEL OF TAX COMPLIANCE IN SAMARINDA CiTY 2012-2014

\begin{tabular}{|c|c|c|c|}
\hline Year & 2012 & 2013 & 2014 \\
\hline Total WPOP (a) & 120.578 & 133.544 & 145.688 \\
\hline $\begin{array}{l}\text { Mandatory Annual } \\
\text { (SPT) (b) }\end{array}$ & 101.829 & 97.527 & 90.778 \\
\hline $\begin{array}{l}\text { Realization Annual } \\
\text { SPT (c) }\end{array}$ & 36.383 & 34.971 & 31.539 \\
\hline $\begin{array}{l}\text { Compliance } \\
\text { (c / b x 100\%) }\end{array}$ & $36 \%$ & $36 \%$ & $35 \%$ \\
\hline
\end{tabular}

According to the Table 1 shows that the increase in the number of registered taxpayers do not necessarily indicate an increase in compliance with the individual taxpayer (WPOP) submitting their annual tax return in 2012 and 2013. The percentage of compliance of the same or different, no changes 
in the number of WPOP increased in 2013 increased to more than 13,000 compared to 2011. Furthermore, in 2014, can be seen a decline in tax compliance presentation to $35 \%$ and it is also not in line with the number of individual taxpayers were increased by more than 15,000 people over the previous year.

Based on previous studies can be seen from a gap of the previous research. Where the variable ethics, tax audit and tax penalties no effect on tax compliance, but there is also mention that the variable has no effect on tax compliance.

\section{A. Taxpayer Compliance}

Compliance was said by [3] is "a climate" awareness of compliance and fulfillment of tax obligations are reflected in the following situations:

- Taxpayers understand or attempt to understand all the provisions of the tax legislation.

- Filling out tax forms completely and clearly.

- Calculating the amount of tax payable correctly.

- Pay taxes owed on time.

Their compliance is because there are rules and norms that should be implemented. Reference [4] states that the success of the tax revenue is the ratio of the level of compliance of tax payment by taxpayers. The higher level of tax compliance, the higher the success rate of tax revenue, and would lead to higher taxation success.

Examples of tax compliance by [5], for example, provisions deadline for submission of income tax returns (SPT VAT) Annual is March 31. If the taxpayer has reported a tax return income (SPT Income Tax) yearly before or on March 31, then the taxpayer has complied with the formal, but its contents do not necessarily comply with the material, which is a state in which the taxpayer is substantive meet all material provisions taxation, ie, according to the contents and spirit of tax law.

\section{B. Ethics Taxpayers}

Ethics comes from the Greek word ethos (singular) meaning: shelter, meadows, stables, habits, customs, character, feelings, attitudes, ways of thinking. Reference [6] senses of ethics can be seen from the following two points:

- Ethics as praxis; equal to morals or morality that mean customs, habits, values, and norms prevailing in society.

- Ethics as a science or ethics is thinking / moral judgments. Ethics as moral thinking mediocre achieve scientific level when the reasoning process to morality is critical, methodical, and systematic. In this stage the science of ethics can only try to formulate a theory, concept, principle, or principles of human behavior that is considered good or not good, why the behavior is considered good or not good, why be either very useful, and so on.

\section{Tax Audits}

Examination of a series of activities to collect and process data, information, and/or evidence carried out objectively and professionally based on a standard of examination to test compliance of tax obligations fulfillment and / or for other purposes in order to implement the provisions of the tax legislation. In Article 29 Paragraph 1 of the Law CTP Directorate General of Taxation is authorized to conduct an audit to verify compliance fulfillment of tax obligations of taxpayers and other purposes in order manage provisions of tax legislation.

The purpose of tax audit is to verify compliance fulfillment of tax obligations:

- SPT overpayments including those already given preliminary tax returns;

- SPT loss;

- SPT is not or late (beyond the time period specified in the Warning Letter) delivered;

- Undertake a merger, consolidation, expansion, liquidation, dissolution, or will leave Indonesia for ever; or

- SPT which meet the selection criteria based on the results of the analysis (risk based selection) indicate a WP tax obligations not being met in accordance with tax legislation. 


\section{Tax Penalties}

Tax penalties occur because of violations of rules of tax laws where the greater the mistakes made by a taxpayer, then the sanction will also be more severe. From the above, sanction or penalty tax may prevent taxpayers to make incompatibility in paying taxes, tax penalties will depend on the error rate payers in fulfilling their obligations. Can be described that the tax penalty is part of the administrative sanctions that must be obeyed by the taxpayer if he violates the rules of the game have been made by the Directorate General of Taxation. Penalty is the kind of sanctions that are mostly found in taxation law. Related penalty amount may beset specified amount,a percentage of the amount or the sum of its multiplication. In a number of violations, penalties will be added to criminal sanctions. Violations are also subject to criminal sanctions are violations that are negligent or intentional.

\section{E. Hypotheses}

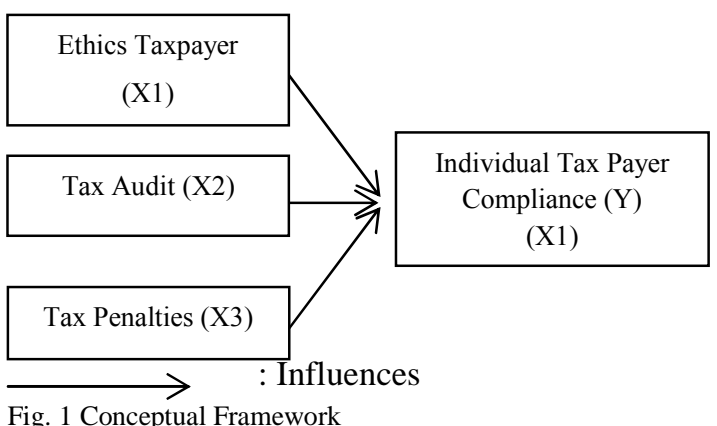

Model hypothesis can be formulated as follows:

H1 : Ethics taxpayer affect the compliance of individual taxpayers.

H2 : Tax assessment affect the compliance of individual taxpayers.

H3: Tax penalties affect the compliance of individual taxpayers.

\section{METHODS}

This study uses a quantitative approach with descriptive methods. According [7] is a descriptive analysis statistical method used to analyze data in ways that describe or depict the data that has been collected as it is without the intention of making conclusions apply to the public, and generalization. Samples are tax inspectors in KPP Samarinda. The study used a sample of saturated when the population is relatively small [7].

\section{RESULTS}

\section{A. Results of Statistical Test}

According to [8], individual taxpayer (WPOP) conducting business are those who carry on business as well in various fields of agriculture, industry, trade, and others and is not bound by a bond with the employer. While generally associated with free job skill or profession carried on by the experts in question are lawyers, accountants, consultants, notaries or doctors who opened consultant office or clinic with their own name.

The criteria used to determine whether or not the statement is valid if the correlation between each of the indicators of the total score constructs showed significant results with the level of $\alpha=0.05 \mathrm{df}=\mathrm{n}$ $2(100-2)=98, r$ table $=0,1966$ then each item will be declared valid question. Based on the analysis, the validity of the test results can be shown as follows:

TABLE II

RESULTS OF VALIDITY TEST

\begin{tabular}{|c|c|c|c|c|}
\hline Variables & $\begin{array}{l}\text { Question } \\
\text { Items }\end{array}$ & $\begin{array}{c}\text { Pearson } \\
\text { Correlation }\end{array}$ & $r$ table & $\operatorname{Exp}$ \\
\hline \multirow{4}{*}{$\begin{array}{c}\text { Taxpayer } \\
\text { Compliance } \\
\text { (Y) }\end{array}$} & Compliance1 & 0.492 & 0.1966 & VALID \\
\hline & Compliance 2 & 0.568 & 0.1966 & VALID \\
\hline & Compliance3 & 0.456 & 0.1966 & VALID \\
\hline & Compliance 4 & 0.719 & 0.1966 & VALID \\
\hline \multirow{4}{*}{$\begin{array}{c}\text { Ethics } \\
\text { Taxpayers } \\
\text { (X1) }\end{array}$} & Ethics1 & 0.756 & 0.1966 & VALID \\
\hline & Ethics2 & 0.387 & 0.1966 & VALID \\
\hline & Ethics3 & 0.484 & 0.1966 & VALID \\
\hline & Ethics4 & 0.594 & 0.1966 & VALID \\
\hline \multirow{4}{*}{$\begin{array}{c}\text { Tax Audit } \\
\text { (X2) }\end{array}$} & Audit1 & 0.581 & 0.1966 & VALID \\
\hline & Audit2 & 0.643 & 0.1966 & VALID \\
\hline & Audit3 & 0.670 & 0.1966 & VALID \\
\hline & Audit4 & 0.549 & 0.1966 & VALID \\
\hline \multirow{3}{*}{$\begin{array}{c}\text { Tax } \\
\text { Penalties } \\
\text { (X3) }\end{array}$} & Penalty1 & 0.798 & 0.1966 & VALID \\
\hline & Penalty2 & 0,517 & 0.1966 & VALID \\
\hline & Penalty 3 & 0,517 & 0.1966 & VALID \\
\hline
\end{tabular}


Table II shows that each item shows the Pearson correlation questions above or bigger than $r$ table is 0.1966 . So that the whole question in this study can be in declared invalid.

The research variables will be said to be reliable if the Cronbach Alpha her have a greater value than $r$ table with a significance of $5 \%$ and the amount of data $(n)=100,0.195$ then the variable is said to be reliable. 4.4 In the table below will explain the results of testing the reliability of the instrument for each of the study variables.

TABLE III.

RESUltS TEST RELIABILITY

\begin{tabular}{|c|c|c|}
\hline Variables & $\begin{array}{c}\text { Cronbach } \\
\text { Alpha } \\
\text { Coefficient }\end{array}$ & $\begin{array}{c}\text { Number Item } \\
\text { Questions }\end{array}$ \\
\hline Taxpayer Compliance & 0.321 & 4 \\
\hline Ethics Taxpayers & 0.503 & 4 \\
\hline Tax audits & 0.429 & 4 \\
\hline Tax penalties & 0.319 & 3 \\
\hline
\end{tabular}

Based on table 4.3 above, it can be seen that the Cronbach alpha coefficient $0.321 ; 0.503 ; 0.423$; and 0.319 so that it can be concluded that the entire instrument in this study is reliable.

TABLE IV.

RESUlTS OF NORMALITY TEST DATA One-Sample Kolmogorov-Smirnov Test

Residual unstandardi

zed

\begin{tabular}{|c|c|c|}
\hline \multicolumn{2}{|l|}{$\mathrm{N}$} & 100 \\
\hline \multirow[t]{2}{*}{ Normal Parametersa, b } & mean &, 0000000 \\
\hline & Std. deviation & 1.56551799 \\
\hline \multirow{3}{*}{$\begin{array}{c}\text { Most Extreme } \\
\text { Differences }\end{array}$} & Absolute &, 061 \\
\hline & positive &, 036 \\
\hline & negative &,- 061 \\
\hline \multicolumn{2}{|c|}{ Test Statistic } &, 061 \\
\hline \multicolumn{2}{|c|}{ Asymp. Sig. (2-tailed) } & , 200C, d \\
\hline
\end{tabular}

a. Test distribution is Normal.

b. Calculated from data.

c. Significance Lilliefors Correction.

$\mathrm{d}$. This is a lower bound of the true significance.
TABLE V. THE AUTOCORRELATION TEST RESULTS

Model Summary

\begin{tabular}{|c|c|c|c|c|c|}
\hline Model & $\mathrm{R}$ & $\begin{array}{c}\text { R } \\
\text { Square }\end{array}$ & $\begin{array}{l}\text { Adjusted } \\
\text { R Square }\end{array}$ & $\begin{array}{l}\text { Std. Error } \\
\text { of the } \\
\text { Estimate }\end{array}$ & $\begin{array}{l}\text { Durbin- } \\
\text { Watson }\end{array}$ \\
\hline 1 & 399a &, 159 &, 133 & 1,590 & 2.095 \\
\hline
\end{tabular}

a. Predictors: (Constant), Tax_Penalties, Ethics_Taxpayers,

Tax_Audit

Based on Table IV and V, and Figure 1, this study set free classical assumption.

\section{B. Regression Analysis}

Analysis of multiple regression test aims to examine the influence of ethics taxpayer, tax audits, and tax penalties on tax compliance individual who carries out business activities and work freely. Based on the results of multiple regeression by using SPSS regression coefficient obtained as follows:

$$
\begin{aligned}
& \text { TABLE VI } \\
& \text { REGRESSION COEFFICIENTS TEST } \\
& \text { COEFFICIENTS A } \\
& \begin{array}{c|c} 
& \text { standardize } \\
\text { Coefficients } & \mathrm{d}
\end{array} \\
& \text { unstandardize Coefficient } \\
& \text { d }
\end{aligned}
$$

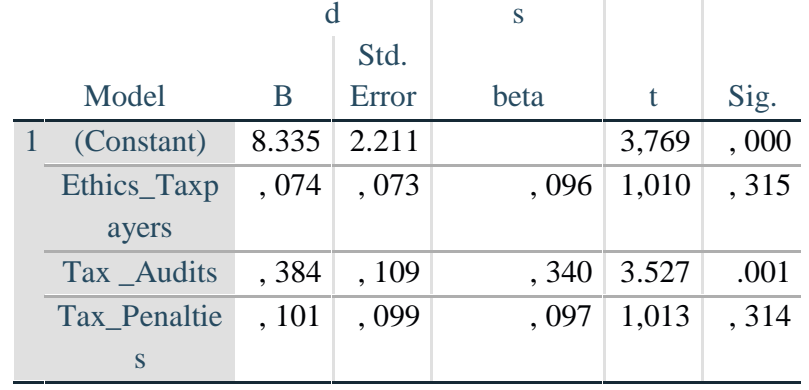

$$
\begin{aligned}
& \text { a. Dependent Variable: Taxpayers_Compliance } \\
& Y=8.335+0.074+0.384 X 1+0.101 X 2 X 3+e
\end{aligned}
$$


C. Hypothesis testing

TABLE VII

TEST Results Hypothesis

ANOVAa

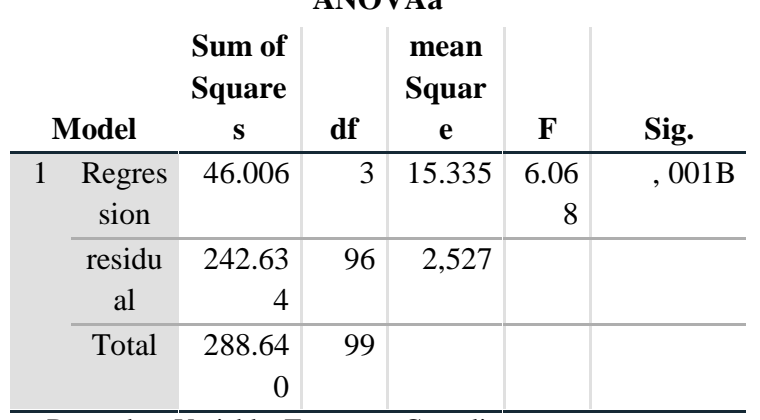

a. Dependent Variable: Taxpayer_Compliance

b. Predictors: (Constant), Tax_Penalties, Ethics_Taxpayers, Tax_Audit

Hypothesis test results in Table VII shows the value of $t$ and the probability of each described as follows:

1. Variable taxpayer ethics showed $t$ values of 1.010 and 0.315 significant. At the alpha of 0.05 and df-nk (100-4) t table 1.985, we conclude that the taxpayer ethics variable has no effect on tax compliance.

2. Variable tax examination showed $t$ values of 3.527 and 0.001 significant. At the alpha of 0.05 and df-nk (100-4) t table 1.985, we conclude that the taxpayer ethics variables significantly influence taxpayer compliance.

3. Variable tax penalty showed $t$ values of 1.013 and 0.314 significant. At the alpha of 0.05 and df-nk (100-4) t table 1.985, we conclude that the taxpayer ethics variable has no effect on tax compliance.

\section{DISCUSSION}

\section{A. Effect of Taxpayers Ethics on Individual Taxpayer} Compliance

Based on the results of hypothesis testing ethics variable taxpayers on tax compliance, suggesting that ethics taxpayer does not affect the compliance of individual taxpayers. So we can say that the first hypothesis $\left(\mathrm{H}_{1}\right)$ is rejected.

Ethics taxpayers increased not affect taxpayer compliance. In this study concludes high or low or whether or not the taxpayer behaves ethics cannot increase the level of tax compliance. List of questions included in the questionnaire study showed many respondents agree will be honest in all aspects, despite that good ethics are shared by most people can not affect the attitude of tax compliance.

Reference [9] conducted a similar study also found that the taxpayer's attitude or ethics in Kenya has no effect on tax compliance. Respondents consisted of 260 samples explain their attitude in Kenya looked at the tax system is unfair. This is because the majority of respondents believe that they pay taxes fairly in accordance with existing regulations.

\section{B. Effect of Tax Audit on Individual Taxpayer Compliance}

The second hypothesis $\left(\mathrm{H}_{2}\right)$ stated that the tax audit for compliance impact to individual taxpayer, the hypothesis testing results indicate that the effect on the tax audits of personal tax compliance. Tests carried out on a regular basis by the Directorate General of Taxation in cooperation with the authorities, making people avoid going to the tax audit measures to report and pay the tax in accordance with tax provisions. An examination also assessed as able to anticipate the level of tax fraud. Directorate General of Taxes also annually determines the tax targets through examination findings, and visits each year tend to increase from the target.

In line with the research done by [10] which concluded due diligence measures significantly influence the improvement of material and formal compliance taxpayer in KPP South Semarang. By applying the self-assessment system, taxpayers are given the confidence to count, deposit and report tax itself into obligations.

\section{Effect of Tax Penalties on Individual Taxpayer Compliance}

The results of hypothesis testing variable tax penalties on tax compliance, suggesting that the tax penalty does not affect the compliance of individual taxpayers. Based on these results it can be said that the third hypothesis $\left(\mathrm{H}_{3}\right)$ was rejected.

Reference [11] concluded that research conducted in Semarang that the fine effect on individuals taxpayers compliance, not in line with a recent study concluded that the tax penalty does not affect the tax payers compliance. This study is in line with research conducted by [12] on the Kenyan society 
stating that the tax penalty has no effect on tax compliance.

\section{CONCLUSIONS}

Ethics Taxpayer does not affect the individual taxpayer Compliance who is registered in the KPP Samarinda. Tax audit affects the Tax Compliance of the individual taxpayer who is registered in the KPP Samarinda. Tax penalty does not affect the individual taxpayer compliance listed in KPP Samarinda. This shows the tax penalty imposed on the taxpayer if the abuse does not affect or improve taxpayer compliance.

Taxpayers in order to continue actively studying the taxation and keep abreast of tax laws in Indonesia. So, that the self-assessment system established by the government can be realized and implemented properly. The tax authority would continue to be increasingly active in performing their duties so that the realization of tax audits tax compliance. Effect of tax audit for compliance testing can be seen from the usefulness of tax audits as detection of fraud committed by corporate taxpayers, oversight of the fulfillment of tax obligations by the taxpayer, and the first step in enforcement (law enforcement).

Tax penalties that have been imposed must be tightened implementation. Penalties imposed on taxpayers who violate must be fair and appropriate for raising awareness of taxpayers to pay their taxes on time and in accordance with the provisions of the Tax Act.

\section{REFERENCES}

[1] Gunadi. [2005]. Fungsi Pemeriksaan Terhadap Peningkatan Kepatuhan Wajib Pajak. Jurnal Perpajakan Indonesia. 4 (5), 4-9.

[2] Tarjo and Indra, Kusumawati. (2006). Analisis perilaku wajib pajak orang pribadi terhadap pelaksanaan self-assesment system: suatu studi di Bangkalan. JAAI 10, (1), 101-120.

[3] Norman D. Nowak. (2007). Tax administration: theory and practice. Washington: Prager Publisher Inc.

[4] Siti, Musyarofah. and Adi, Purnomo. (2008). Pengaruh Kesadaran dan Persepsi tentang Saksi, dan Hasrat Membayar Pajak terhadap Kepatuhan Wajib Pajak. Jurnal Akuntansi, Manajemen Bisnis dan Sektor Publik, 5 (1), 34-50.

[5] Safri, Nurmatu. (2007). Pengantar perpajakan. Jakarta: Granit.

[6] Sukrisno, Agoes. and Cenik, Ardana. (2009). Etika bisnis dan profesi. Jakarta: Salemba Empat.

[7] Sugiyono (2011). Metode penelitian kuantitatif, kualitatif dan $R \& D$. Bandung: Alfabeta.

[8] Kantor Pajak Pratama. (2015). Sistem informasi direktorat jenderal pajak. Samarinda.

[9] Lumumba, Omweri Marti. Migwi, S. Wanjohi. Peterson, Obara Magutu. and John, Mageto Mokoro. (2008). Taxpayers, attitudes and tax compliance behaviour in Kenya. African Journal of Business \& Management (AJBUMA), 1, 112-122.

[10] Dwi, Rahayu. (2011). Analisis pengaruh pemeriksaan pajak terhadap kepatuhan wajib pajak pada kantor pelayanan pajak pratama Semarang selatan. Jurnal Ekonomi Manajemen Akuntansi, 18, (30).

[11] Santi, Anisa Nirmala. (2011). Analisis Pengaruh Kesadaran Perpajakan, Sikap Rasional, Lingkungan, Sanksi Denda dan Sikap Fiskus Terhadap Kepatuhan Wajib Pajak (Studi Empiris Pada WPOP di Wilayah KPP Pratama Semarang). Jurnal Investasi, 8 (1), 15 - 32.

[12] Adesina, Olugoke Oladipupo. and Uyioghosa, Obazee. (2016). Tax knowledge, penalties and tax compliance in small and medium scale enterprises in Nigeria. Journal iBusiness, 8, 1-9. 